\title{
Front Matter: Volume 11687
}

, "Front Matter: Volume 11687," Proc. SPIE 11687, Oxide-based Materials and Devices XII, 1168701 (27 April 2021); doi: 10.1117/12.2596755

SPIE. Event: SPIE OPTO, 2021, Online Only 


\title{
PROCEEDINGS OF SPIE
}

\section{Oxide-based Materials and Devices XII}

\author{
David J. Rogers \\ David C. Look \\ Ferechteh H. Teherani \\ Editors
}

6-11 March 2021

Online Only, United States

Sponsored and Published by

SPIE 
The papers in this volume were part of the technical conference cited on the cover and title page. Papers were selected and subject to review by the editors and conference program committee. Some conference presentations may not be available for publication. Additional papers and presentation recordings may be available online in the SPIE Digital Library at SPIEDigitalLibrary.org.

The papers reflect the work and thoughts of the authors and are published herein as submitted. The publisher is not responsible for the validity of the information or for any outcomes resulting from reliance thereon.

Please use the following format to cite material from these proceedings:

Author(s), "Title of Paper," in Oxide-based Materials and Devices XII, edited by David J. Rogers, David C. Look, Ferechteh H. Teherani, Proc. of SPIE 11687, Seven-digit Article CID Number (DD/MM/YYYY); (DOI URL).

ISSN: 0277-786X

ISSN: 1996-756X (electronic)

ISBN: 9781510642096

ISBN: 9781510642102 (electronic)

Published by

SPIE

P.O. Box 10, Bellingham, Washington 98227-0010 USA

Telephone +1 3606763290 (Pacific Time)

SPIE.org

Copyright @ 2021 Society of Photo-Optical Instrumentation Engineers (SPIE).

Copying of material in this book for internal or personal use, or for the internal or personal use of specific clients, beyond the fair use provisions granted by the U.S. Copyright Law is authorized by SPIE subject to payment of fees. To obtain permission to use and share articles in this volume, visit Copyright Clearance Center at copyright.com. Other copying for republication, resale, advertising or promotion, or any form of systematic or multiple reproduction of any material in this book is prohibited except with permission in writing from the publisher.

Printed in the United States of America by Curran Associates, Inc., under license from SPIE.

Publication of record for individual papers is online in the SPIE Digital Library.

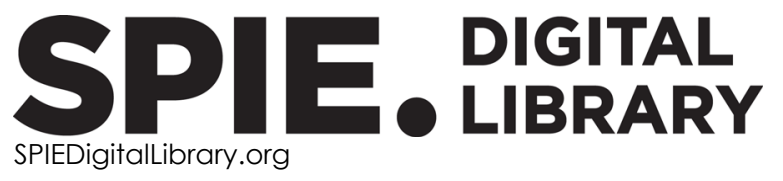

Paper Numbering: A unique citation identifier (CID) number is assigned to each article in the Proceedings of SPIE at the time of publication. Utilization of CIDs allows articles to be fully citable as soon as they are published online, and connects the same identifier to all online and print versions of the publication. SPIE uses a seven-digit CID article numbering system structured as follows:

- The first five digits correspond to the SPIE volume number.

- The last two digits indicate publication order within the volume using a Base 36 numbering system employing both numerals and letters. These two-number sets start with 00, 01, 02, 03, 04, 05, 06, 07, 08, 09, 0A, OB ... 0Z, followed by 10-1Z, 20-2Z, etc. The CID Number appears on each page of the manuscript. 


\section{Contents}

\section{GALLIUM OXIDE MATERIALS AND DEVICES I}

1168707 Enhancing the dielectric constant of oxides via acceptor-donor co-doping (Invited Paper) [11687-4]

1168709 Split Ga vacancies: abundant defects in $\beta-\mathrm{Ga}_{2} \mathrm{O}_{3}$ (Invited Paper) [1 1687-6]

$11687 \mathrm{OE} \quad$ Trapping processes and band discontinuities in $\mathrm{Ga}_{2} \mathrm{O}_{3}$ FinfETs investigated by dynamic characterization and optically-assisted measurements [1 1687-10]

\section{GALLIUM OXIDE MATERIALS AND DEVICES II}

$116870 Q \quad$ Progress in atomic layer deposited a- $\mathrm{Ga}_{2} \mathrm{O}_{3}$ materials and solar-blind detectors (Invited Paper) [11687-20]

11687 OT Detailed investigation of $\mathrm{MOCVD}$ grown $\beta-\mathrm{Ga}_{2} \mathrm{O}_{3}$ through quantitative defect spectroscopies (Invited Paper) [11687-23]

FIRST-PRINCIPLE CALCULATIONS OF MATERIAL AND DEVICE PROPERTIES

$116870 X \quad$ First-principles calculations of $\mathbf{N}$ - and P-type doping in wurtzite and zincblende GaN (Invited Paper) [11687-27]

\section{PLASMONICS}

1168712 La-doped $\mathrm{BaSnO}_{3}$ films for near- and mid-infrared plasmonic applications [1 1687-32]

1168713 The role of oxide defect chemistry in the drude and plasmonic response of optical fiber-based sensing layers for high-temperature gas sensing [1 1687-33]

ZINC OXIDE MATERIALS AND DEVICES

$11687 \mathrm{IE}$ Investigation of the optical, electrical, and elemental properties upon annealing of spatial atomic layer deposited (SALD) Al-doped ZnO thin films [1 1687-44] 


\section{OXIDE THIN-FILM TRANSISTORS}

$11687 \mathrm{lF} \quad$ Bendable metal oxide thin-film transistors and circuits for analog electronics applications (Invited Paper) [1 1687-46]

$116871 G \quad$ Oxide transistors: unconventional architectures and their applications (Invited Paper) [11687-47]

$1168711 \quad$ Aluminum oxide as a dielectric and passivation layer for (flexible) metal-oxide and 2D semiconductor devices (Invited Paper) [11687-49]

OXIDE-BASED EMERGING PROCESSES AND APPLICATIONS I

$116871 \mathrm{~L} \quad$ Oxides based resistive switching memories (Invited Paper) [11687-52]

$116871 \mathrm{U}$ Effect of annealing on properties and performance of $\mathrm{HfO}_{2} / \mathrm{SiO}_{2}$ optical coatings for UV-applications [1 1687-60]

\section{OXIDE-BASED EMERGING PROCESSES AND APPLICATIONS II}

11687 1X Synthesis of low dimensional oxide based complex materials by a vapor-solid method (Invited Paper) [1 1687-62]

11687 1Y A walk on the frontier of energy electronics with power ultra-wide bandgap oxides and ultra-thin neuromorphic 2D materials (Invited Paper) [1 1687-63]

1168712 Chemical beam vapor deposition technique with Sybilla equipment: review of main results in its 20-year anniversary (Invited Paper) [1 1687-64]

\section{POSTER SESSION}

1168725 Parity-Time symmetry in lasers with nonuniform and segmented gain [1 1687-69]

1168727 Lanthanide-doped down-conversion fluorides: synthesis, characterization, and applications [11687-71]

11687 2A Mg-related charge transitions in $\mathbf{M g - d o p e d ~} \mathrm{Ga}_{2} \mathrm{O}_{3}$ [1 $\left.1687-74\right]$

$116872 \mathrm{D} \quad$ Sharp/tuneable UVC selectivity and extreme solar blindness in nominally undoped $\mathrm{Ga}_{2} \mathrm{O}_{3} \mathrm{MSM}$ photodetectors grown by pulsed laser deposition [1 1687-82] 